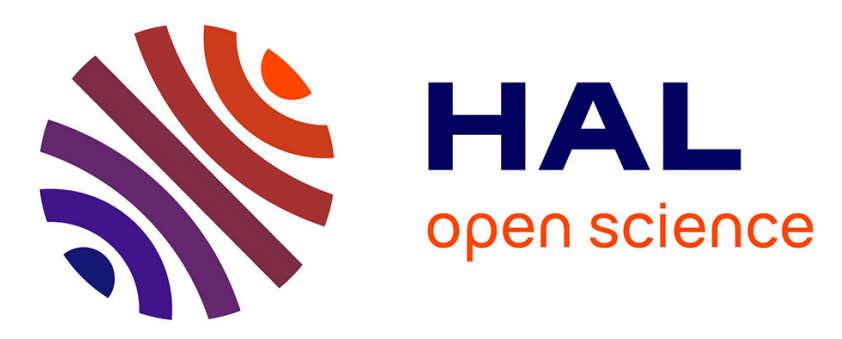

\title{
Analysis of the juice and water losses in salted and unsalted pork samples heated in water bath. Consequences for the prediction of weight loss by transfer models
}

Laure Bombrun, Philippe P. Gatellier, Stéphane S. Portanguen, Alain Kondjoyan

\section{To cite this version:}

Laure Bombrun, Philippe P. Gatellier, Stéphane S. Portanguen, Alain Kondjoyan. Analysis of the juice and water losses in salted and unsalted pork samples heated in water bath. Consequences for the prediction of weight loss by transfer models. Meat Science, 2015, 99, pp.113-122. 10.1016/j.meatsci.2014.07.033 . hal-02638742

\section{HAL Id: hal-02638742 \\ https://hal.inrae.fr/hal-02638742}

Submitted on 28 May 2020

HAL is a multi-disciplinary open access archive for the deposit and dissemination of scientific research documents, whether they are published or not. The documents may come from teaching and research institutions in France or abroad, or from public or private research centers.
L'archive ouverte pluridisciplinaire HAL, est destinée au dépôt et à la diffusion de documents scientifiques de niveau recherche, publiés ou non, émanant des établissements d'enseignement et de recherche français ou étrangers, des laboratoires publics ou privés. 


\title{
Analysis of the juice and water losses in salted and unsalted pork samples heated in water bath. Consequences for the prediction of weight loss by transfer models
}

\author{
Laure Bombrun $^{\mathrm{a}, \mathrm{b}}$, Philippe Gatellier ${ }^{\mathrm{b}}$, Stéphane Portanguen ${ }^{\mathrm{b}}$, Alain Kondjoyan ${ }^{\mathrm{b}, *}$ \\ a IFIP, French institute for the pig and pork industry, F-94700 Maisons-Alfort, France \\ b INRA, UR370 Qualité des Produits Animaux, F-63122 Saint-Genès-Champanelle, France
}

\section{A R T I C L E I N F O}

\section{Article history:}

Received 4 September 2013

Received in revised form 23 July 2014

Accepted 30 July 2014

Available online 7 August 2014

\section{Keywords:}

Weight loss

Sample dimensions

Boundary conditions

Muscle type

Salt content

Modeling

\begin{abstract}
A B S T R A C T
This study has analyzed the effect of different factors on variation of meat weight due to juice loss, and variation of water content of pork samples heated in a water bath. The weight loss (WL) was influenced by initial water content of raw meat which can be connected to meat $\mathrm{pH}$, muscle type, and by pre-salting. WL was also influenced by sample thickness and by nature of the surrounding fluid. These effects were significant at $50{ }^{\circ} \mathrm{C}$ and in thinner samples but decreased as meat temperature and sample thickness increased. WL showed no significant difference in response to prior freezing, applying a surface constraint during heating or varying meat salt content from 0.8 to $2.0 \%$. The results were interpreted from literature knowledge on protein denaturation, contraction and, transport phenomena. Reliably predicting WL from water content variation during heating hinges on taking into account the loss of dry matter and the possible effects of meat pH, sample size or surrounding fluid.
\end{abstract}

(c) 2014 Published by Elsevier Ltd.

\section{Introduction}

When cooking meat, weight loss (WL) increases with cooking time until reaching an essentially temperature-dependent equilibrium state (Oillic, Lemoine, Gros, \& Kondjoyan, 2011). Weight loss is due to the migration of juice out of the meat which affects both technological yield and meat quality (juiciness, tenderness, loss of nutritional components, etc.) (Aaslyng, Bejerholm, Ertbjerg, Bertram, \& Andersen, 2003; Oillic et al., 2011). Meat processing often adds salt (cooked ham, sausages, etc.) but, industry is under pressure to reduce salt content for health reasons (Desmond, 2006). Understanding and predicting variations of the weight losses from unsalted or "lightly salted" meat is therefore a key challenge for both industry and consumers.

The two main theories to explain variation in raw meat waterholding capacity were reviewed by Puolanne and Halonen (2010) and, Huff-Lonergan and Lonergan (2005), who basically recapped earlier theories developed by Hamm (1972) and Offer and Knight (1988) based on electrostatic, osmotic forces, and a modification of the charge of proteins at lower $\mathrm{pH}$ caused by the production of lactic acid. Moisture transfer and WL can also be related to thermodynamics phenomena

\footnotetext{
* Corresponding author. Tel.: + 334736244 92; fax: + 33473624089

E-mail address: alain.kondjoyan@clermont.inra.fr (A. Kondjoyan).
}

using the Flory-Rehner theory. The water flux is then connected to the variation of the swelling pressure which included three contributions: a contribution due to the mixing of proteins and water, a contribution of ions and polyelectrolytes and the elastic deformation of the crosslinked protein network (van der Sman, 2013).

During heating, two phenomena contribute to juice loss: water debinding and meat contraction. Water debinding is caused by protein structural changes due to decreasing water-protein bonding. Water debinding begin from $40{ }^{\circ} \mathrm{C}$ due to the structural changes of myofibrillar proteins (Davey \& Gilbert, 1974; Promeyrat, Daudin, \& Gatellier, 2013). Then, water migration is caused by meat contraction, principally due to collagen shrinkage. Indeed, meat contraction and variation in meat piece volume directly correlate to weight loss (Davey \& Gilbert, 1974) and meat water content (Bouhrara, Clerjon, Damez, Kondjoyan, \& Bonny, 2012). Meat contraction begin at $40{ }^{\circ} \mathrm{C}$ and accelerates at about $60{ }^{\circ} \mathrm{C}$ (Bouhrara et al., 2012), which corresponds to the collagen denaturation temperature measured by differential scanning calorimetry (DSC) (Tornberg, 2005).

Numerous studies have investigated the impact of raw material properties (sample dimension, muscle type, animal species) and process (cooking, injection rate, and type of packaging) on weight loss. Table 1 gives a short literature review. Many studies disregard the influence of heating kinetics on weight loss. Heating kinetics depends on both sample dimensions and on type and control of the heating 
Table 1

Literature review on the effect of raw material and processes on weight losses and water content in cooked meat.

\begin{tabular}{|c|c|c|}
\hline Subject & Authors & Conclusions \\
\hline \multicolumn{3}{|l|}{ Impact of raw material } \\
\hline Effect of dimension & $\begin{array}{l}\text { Bouton et al. (1976); Oillic et al. } \\
\text { (2011) }\end{array}$ & $\begin{array}{l}\text { - By determining heating rate, sample size had a major effect on } \mathrm{WL}^{*} \text { for quick heating but had no } \\
\text { impact on equilibrium } \mathrm{WL}^{*}\end{array}$ \\
\hline Effect of muscle type & $\begin{array}{l}\text { Jeremiah et al. (2003); Rhee et al. } \\
\text { (2004) }\end{array}$ & $\begin{array}{l}\text { - WL* is dependent on muscle type, but the ranking of muscle types remains controversial between } \\
\text { studies }\end{array}$ \\
\hline Effect of animal species & Oillic et al. (2011) & $\begin{array}{l}\text { - Highly significant difference in water content of raw SM** (from } 2.9 \mathrm{~g} / \mathrm{gDM} \text { for horse to } 3.4 \mathrm{~g} / \mathrm{gDM} \\
\text { for lamb) but minor difference between species in equilibrium } \mathrm{WL}^{*} \text { of } \mathrm{SM}^{* *}\end{array}$ \\
\hline $\begin{array}{l}\text { Effect of sampling } \\
\text { Effect of pre-freezing }\left(-20^{\circ} \mathrm{C}\right)\end{array}$ & $\begin{array}{l}\text { Rhee et al. (2004); Oillic et al. } \\
\text { (2011); Utrera et al. (2012) }\end{array}$ & $\begin{array}{l}\text { - Difference in } \mathrm{CL}^{*} \text { in a single muscle can reach } 3 \% \text { depending on the sampling location. } \\
\text { - Pre-freezing had no significant effect on } \mathrm{WL}^{*} \text {, nor on moisture content }\end{array}$ \\
\hline \multicolumn{3}{|l|}{ Impact of meat processing } \\
\hline \multirow[t]{2}{*}{ Effect of injection rate } & Desmond et al. (2002) & - Injection rate (20-35\%) did not influence moisture content in cooked meat \\
\hline & Boles \& Shand (2001) & - Slight decrease in moisture content in cooked meat when injection rate increased from 10 to $25 \%$ \\
\hline Effect of packaging & Cheng and Sun (2007) & - Ham cooked with a cooking bag had lower WL* than without a bag \\
\hline $\begin{array}{l}\text { Effect of type of cooking: } \\
\text { water vs. wet air }\end{array}$ & Cheng et al. (2005) & - No difference in moisture content in cooked ham nor in $\mathrm{WL}^{*}$ for water or wet-air cooking \\
\hline
\end{tabular}

$* \mathrm{WL}=$ Weight loss

** $\mathrm{SM}=$ Semimembranosus

equipment (Kondjoyan et al., 2014). When heating trials end before the equilibrium state is reached, the reported differences can often be explained by variation in the heating conditions leading to variation of the factor studied (Oillic et al., 2011). Looking at the effect of salt content, results differ between studies. A majority of studies show that reducing added salt content in meat from 1.5 to $1.0,0.5 \%$ or $0.0 \%$ increases weight loss when the meat is cooked to a core temperature of about $70{ }^{\circ} \mathrm{C}$. This conclusion applies to restructured pork ham (Lee \& Chin, 2011), pork or beef sausages (Puolanne, Ruusunen, \& Vainionpaa, 2001; Sikes, Tobin, \& Tume, 2009), pork meatballs (Hsu \& Yu, 1999), and pork or beef muscles (Baublits, Pohlman, Brown, Yancey, \& Johnson, 2006; Detienne \& Wicker, 1999; Vaudagna et al., 2008) cooked in a water bath, and has been verified for ground pork ham cooked in a microwave oven (Jeong et al., 2007). However, a few studies have found a much lower effect of changing salt content. Villamonte, Simonin, Duranton, Cheret, and de Lamballerie (2013) found no significant difference in weight loss between unsalted and $1.5 \%$-salted pork, even if weight loss did tend to decrease.

Weight loss in meat can be usefully modeled to predict the influence of process factors and avoid expensive technological trials. Several modeling approaches have recently been developed in the literature to predict weight loss in meat (Goni \& Salvadori, 2010; Kondjoyan, Oillic, Portanguen, \& Gros, 2013a; van der Sman, 2007, 2013). Whatever the approach, the prediction of the water transport is always based on the difference between water content in the cooked meat and the equilibrium water content $\left(\mathrm{X}_{\mathrm{eq}}\right)$. Water content is considered to be at equilibrium when loss is no longer observed whatever the duration of treatment. Experimental $\mathrm{X}_{\mathrm{eq}}$ are generally fitted using a sigmoid function (Goni \& Salvadori, 2010; van der Sman, 2007, 2013) (Eq. (1)).

$X_{e q}(T)=a_{0}-\frac{a_{1}}{1+a_{2} \exp \left(a_{3}\left(T-T_{r}\right)\right)}$

$\mathrm{T}$ is the sample temperature, $\mathrm{a}_{0}$ indicated the initial water content while $T_{r}$ a reference temperature; $a_{1}, a_{2}, a_{3}$, and $T_{r}$ are unknown parameters which shall be determined from experimental results.

Reliable prediction of weight loss hinges on knowing the precise equilibrium water content value (Oillic et al., 2011). Analysis of transfer phenomena and literature results leads to the conclusion that equilibrium weight loss and equilibrium water content can be affected by raw meat properties, sample dimensions or presence of packaging. It had also been found during a previous study on unsalted beef meat that weight loss during cooking was affected by muscle type and unaffected by pre-cooking processes such as freezing and thawing (Oillic et al.,
2011). Thus, a first set of experiment was performed on unsalted pork meat to check whether previous conclusions were also true for pork meat and whether the effect of muscle type can be explained by variations in the initial $\mathrm{pH}$ value and in the initial water content of the raw meat. These experiments were completed to analyze the effect of sample dimensions and packaged or unpackaged conditions on the equilibrium water content and weight losses. A third set of experiments was performed on salted samples (without addition of polyphosphates). The influence of salt content was studied both on thin samples, which were uniformly salted without tumbling, and on bigger samples, salted under controlled gentle tumbling conditions. All these results have been interpreted in the light of the literature theories which explain waterprotein debinding and water migration. They were also used to discuss the results of the literature models which use measured water contents to predict the loss of weight during cooking.

\section{Materials and methods}

\subsection{Meat cuts}

Experiments were performed on 4 different pork muscles from ten hams, i.e. Semimembranosus (SM), Biceps femoris (BF), Rectus femoris (RF) and Semitendinosus (ST), and one dorsal muscle, i.e. Longissimus thoracis (LT). The four muscles mentioned above were taken from ham of each animal. The meat came from a batch purchased from an industrial manufacturer and considered by him as being homogeneous (drawn at random from a batch for the production of cooked ham). The pigs used were "Piétrain" breed and had a carcass weight of $90 \mathrm{~kg}$ on average. The average mass of the hams (with bone) was $10 \mathrm{~kg}$. The muscles were vacuum-packed as soon they were received in the laboratory. The majority of them was frozen before experimentation: whole muscles was slowly frozen at $-20{ }^{\circ} \mathrm{C}$ and kept frozen less than a month. To study the impact of pre-freezing, three Semimembranosus muscles were kept fresh. Samples were cut in fresh or frozen meat (for one week) into $40 \times 5 \mathrm{~mm}$-thick discs (diameter $40 \mathrm{~mm}$ ) with a slicer or $30 \times 30 \times 30 \mathrm{~mm}$ and $50 \times 50 \times 50 \mathrm{~mm}$ cubes (accuracy $1 \mathrm{~mm}$ ) with a knife. Frozen samples were vacuum-packed and then immersed in a water bath at $14{ }^{\circ} \mathrm{C}$ to be thawed until their core temperature reached $10{ }^{\circ} \mathrm{C}$. Pre-manipulations were performed locating a thermocouple at the center of the samples to determine the time needed to reach a core temperature of $10^{\circ} \mathrm{C}$ depending on the samples dimensions. The meat was then cooked vacuum-packed in a water bath at $70{ }^{\circ} \mathrm{C}$ for $5,15,60$ or $120 \mathrm{~min}$.

Water content and $\mathrm{pH}$ were measured in six replicates per fresh or thawed raw muscle used. Water content in raw meat $\left(\mathrm{X}_{0}\right)$ was 
determined by drying 3 to $10 \mathrm{~g}$ ( $5 \mathrm{~g}$ on average taken on scraps of muscles) of sample for $24 \mathrm{~h}$ in an oven at $104^{\circ} \mathrm{C}$ (ED240, Binder, Germany) and by accurately weighing the sample before $\left(\mathrm{m}_{\mathrm{DM}+\mathrm{w}}\right)$ and after drying $\left(\mathrm{m}_{\mathrm{DM}}\right.$, Eq. (2)). $\mathrm{X}_{0}$ is expressed in $\mathrm{g}$ of water $/ \mathrm{g}$ of dry matter (DM).

$X_{0}=\frac{m_{D M+w}-m_{D M}}{m_{D M}}$

$\mathrm{m}_{\mathrm{DM}+\mathrm{w}}$ being the mass of dry matter plus water and, $\mathrm{m}_{\mathrm{DM}}$ the mass of dry matter.

$\mathrm{pH}$ was measured with a penetration sensor (Inlab® Solids, Mettler Toledo and MP230 pH-meter, Mettler Toledo, Switzerland) on $0.6 \mathrm{~g}$ of meat ground with $300 \mu \mathrm{L}$ of pure water.

To investigate the distribution of water in the same muscle, a 70 × 30 x $23 \mathrm{~mm}$ parallelepiped of pork Semimembranosus muscle was cut into 27 samples to measure water content.

\subsection{Meat salting}

Some of the experiments were performed on salted meat. Different salting processes were used to salt the raw meat, depending on the sample dimensions. All of these methods used brine composed solely of water and sodium chloride. Two methods were used to salt disc samples. In the first case, brine ( $6 \%$ by weight) was coated on each disc face for 50 hours, avoiding evaporation (each sample placed in a box covered by a lid), until the meat had absorbed all the brine. It has been empirically determined that salt content in brine has to be 90 , 150 and $200 \mathrm{~g} / \mathrm{L}$ to reach $0.8,1.3$ and $2.0 \%$ in meat, respectively. In the second case, the discs were immersed in a bioreactor (Labfors, Infors HT, Switzerland) for $17 \mathrm{~h}$ in brine containing 11 or $27 \mathrm{~g} / \mathrm{L}$ sodium chloride to reach 0.8 and $2.0 \%$ in meat, respectively (the previously mentioned bioreactor was used to control $\mathrm{pH}$, temperature and stirring). The brines were stirred at $200 \mathrm{rpm}$ and kept at $5{ }^{\circ} \mathrm{C}$ and $\mathrm{pH}=5.6$. The $\mathrm{pH}$ in the bioreactor was automatically controlled by adding hydrochloric acid or sodium hydroxide which ensured that the target $\mathrm{pH}$ value (here 5.6) was reached in the meat. Moreover, the use of a bioreactor made it possible to artificially increase the water content in the raw meat in order to study the effect of this initial water content on the weight loss of the sample when heated afterwards in the water bath. Working with thin samples that are saltable without tumbling eliminated the tumbling effect. Concerning cubes, tumbling was inevitable to reduce the salting time. In this case, brines were formulated with $110,165,220$ or $270 \mathrm{~g}$ of $\mathrm{NaCl}$ per liter to reach $0.8,1.3,1.6$ and $2.0 \%$ in meat, respectively. Cubes were vacuum-packed with $10 \%$ (by weight) of brine and were intermittently tumbled ( $8 \mathrm{rpm}$ for a total of 2,064 rotations at $2{ }^{\circ} \mathrm{C}$, Inject Star, Austria).

Salt content in salted raw meat was measured by deducing chloride anions by ion chromatography ( 850 professional IC, Metrohm, France) for which $0.5 \mathrm{~g}$ of meat homogenized in $10 \mathrm{~mL}$ of pure water was centrifuged at room temperature $(11,300 \mathrm{rpm}, 10 \mathrm{~min}) 0.2 \mathrm{~mL}$ of the supernatant was collected and diluted in $10 \mathrm{~mL}$ of pure water to measure chloride content.

The influence of salt content on equilibrium state after cooking was studied on $40 \times 5-\mathrm{mm}$ discs and tumbled $30 \times 30 \times 30-\mathrm{mm}$ cubes of Semimembranosus pork muscles cooked vacuum-packed at 50 to $90{ }^{\circ} \mathrm{C}$.

\subsection{Thermal treatments}

Samples were suspended in a thermostat-controlled water bath at a constant temperature of $50,55,60,65,70,75,80,85$ or $90^{\circ} \mathrm{C}$ (WNB 29 , Memmert, Germany). In the bath water flow was due to freeconvection. The samples were heated until the equilibrium time was reached. That means until the temperature of the sample and its weight remained constant. This equilibrium time depended on sample dimensions i.e. $60 \mathrm{~min}$ for $40 \mathrm{x} 5-\mathrm{mm}$ discs, $120 \mathrm{~min}$ for $30 \mathrm{x}$ 30 x 30-mm cubes and $240 \mathrm{~min}$ for 50 x 50 x 50-mm cubes. Premanipulations were performed locating thermocouples at the center of the cube samples to determine the time needed for the core temperature to reach the water bath temperature. For disc the shortest time needed to reach equilibrium was determined by calculations using a heat transfer model. However, this time was not enough to reach equilibrium since, as it had been observed in a previous work, mass transfer was much slower than the heat transfer (Oillic et al., 2011). Thus, equilibrium times were determined by weighting the samples until no more weight loss was observed. In practice an additional period was added to these time values to be sure to be at equilibrium. At the end of the experiment the samples were removed from the water bath and cooled for $10 \mathrm{~min}$ in iced water.

Presence of packaging influences the boundary conditions by changing the fluid in contact with the meat: when meat is cooked unpacked in a water bath, the surrounding fluid is water while it is meat juice when meat is cooked vacuum-packed (Multivac A 200/15, Multivac, France). Four packaging conditions were tested either with $40 \times 5 \mathrm{~mm}$ discs or with 30 x 30 × 30 mm cubes: 1) meat samples were cooked unpacked in the water bath at a constant temperature; 2) samples were individually vacuum-packed ( $-0.9 \mathrm{bar}$, in $90 \mu \mathrm{m}$ thick bags made of polyethylene and polyamide, and cooked in the water bath; 3) samples were individually vacuum-packed and placed in an aluminium mold (ensuring efficient heat transfer); 4) samples were individually vacuum-packed, placed in an aluminium mold and a $1 \mathrm{~kg}$-deadweight was put on the meat.

Samples were wiped with absorbent paper and weighed before heating $\left(\mathrm{m}_{0}\right)$ and after heating and cooling $\left(\mathrm{m}_{\mathrm{f}}\right)$. Weighting loss $(\mathrm{WL})$, expressed as a percentage, was calculated from Eq. (3).

$W L=\frac{m_{0}-m_{f}}{m_{0}} \times 100$

Cooking juice is often assimilated to water but this is not true as dry matter is also flowing out of the meat with the water. In the recent modeling studies of literature the mass transfer is calculated based on difference of water content in the raw and in the cooked meat (Feyissa, Gernaey, \& Adler-Nissen, 2013; Goni \& Salvadori, 2010; Kondjoyan et al., 2013a; van der Sman, 2007, 2013). In a previous study the following relation was used to calculate the weight loss from the initial water content in the raw meat $X_{0}$ and from the water content at a given time in the heated meat X, (Oillic et al., 2011):

$W L=\frac{X_{0}-X}{1+X_{0}} \times 100$

In this relation the water contents are expressed on a dry matter basis and it is assumed that the variation of weight due to the loss of dry matter is negligible compared to the water loss. This assumption was correct on big cubes and for short or moderate cooking time. However, in present study it was measured during preliminary trials that up to $6.40 \%$ of dry matter was contained in the juice under the long heating of the $40 \times 5-\mathrm{mm}$ thick discs at $90^{\circ} \mathrm{C}$. In this case, the loss of dry matter in the juice was not negligible compared to the water loss. Moreover since the water content was expressed as a \% of dry matter in the meat the water content in the heated meat X, was overestimated compared to the water content in the raw meat $\mathrm{X}_{0}$. This led to under-predictions of the weight loss by relation (4). This was a problem because an important objective of this paper was to determine the effect of different factors on the weight loss and to discuss the ability of the transfer models to predict this weight loss. Thus, the measured value of the water content in the heated meat at equilibrium $\mathrm{X}_{\mathrm{eq}}$, was determined from the weight loss measurements in order to compensate for the dry matter loss and to be able to use the $\mathrm{X}_{\mathrm{eq}}$ values in the future in 
mass transfer models to predict weight losses without bias under conditions which will be different from those encountered in this paper:

$X_{e q}=X_{0}-\frac{W L}{100} \cdot\left(1+X_{0}\right)$

The loss of dry matter in the meat during heating ( $\left.\mathrm{L}_{\mathrm{DM}}\right)$ was also theoretically calculated using the water contents measured (Eq. (2)) in the heated, $\mathrm{X}_{\mathrm{m}}$, and in the raw meat, $\mathrm{X}_{0}$, by:

$L_{D M}=1-\frac{D M}{D M_{0}}=\left(1-\frac{\left(1-\frac{C L}{100}\right) \cdot\left(1+X_{0}\right)}{1+X_{m}}\right) \times 100$

To fit the experimental $\mathrm{X}_{\mathrm{eq}}$-curve with the sigmoid function in Eq. ( 1 ), the coefficients $\left(a_{0}, a_{1}, a_{2}, a_{3}\right.$ and $\left.T_{r}\right)$ were optimized by minimizing the sum of squared difference between measured and predicted equilibrium water contents at each temperature.

\subsection{Statistics}

The factors selected from literature as being likely to affect the weight loss were: temperature $\left(50,55,60,65,70,75,80,85\right.$ or $\left.90^{\circ} \mathrm{C}\right)$, sample dimension ( $40 \times 5-\mathrm{mm}$ discs, $30 \times 30 \times 30 \mathrm{~mm}$ or $50 \times 50 \times 50$ mm cubes), presence of packaging, type of muscle (SM, BF, RT, ST or LT), initial water content and $\mathrm{pH}_{0}$ in the raw meat, prior freezing and salting $(0.8,1.3,1.6$ or $2.0 \%)$ of the raw meat. Each trial was repeated at least three times, giving a total of more than 300 heated samples. Results are reported in the following as means \pm standard error of the mean (SEM). ANOVA was performed to compare means, and levels of statistical significance between groups were assessed using a Tukey test. Level of significance was set at 5\%. Correlations were tested using the Pearson coefficient. Statistical analyses were performed using R versions 2.12.2 software.

\section{Results and discussion}

Weight loss increased with time until equilibrium (Fig. 1). Once equilibrium state was reached, weight loss and water content in meat plateaued. The results reported here are mostly at equilibrium state, i.e. equilibrium water content $\left(\mathrm{X}_{\mathrm{eq}}\right)$, equilibrium Weight loss $\left(\mathrm{WL}_{\mathrm{eq}}\right)$ and equilibrium DM loss $\left(\mathrm{L}_{\mathrm{DM}}\right)$. The influence of studied parameters on weight loss was analyzed using the results obtained in literature on

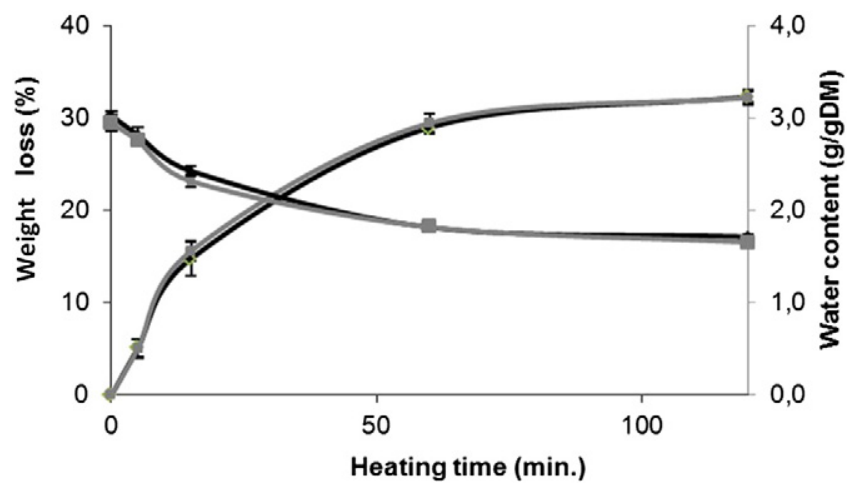

Fig. 1. Evolution of weight loss and water content during heating and impact of prior freezing on cooking loss curve and water content curve for 30 × 30 x 30-mm cubes of pork Semimembranosus muscle cooked vacuum-packed in a water bath at $70{ }^{\circ} \mathrm{C}$. Black line: non-frozen samples; gray line: pre-frozen and thawed samples.
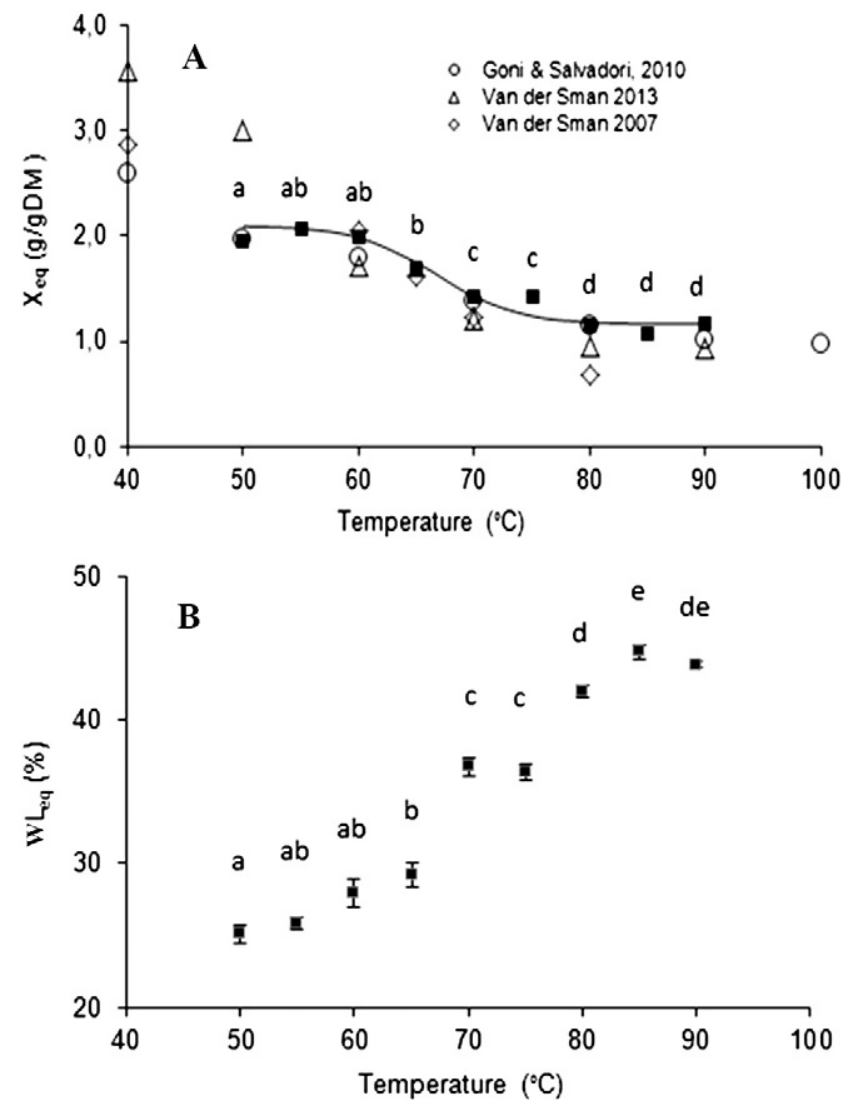

Fig. 2. Impact of temperature on $A$ ) equilibrium water content $\left(X_{e q}\right)$ and $B$ ) equilibrium cooking loss $\left(\mathrm{WL}_{\mathrm{eq}}\right)$ in $5-\mathrm{mm}$ discs of pork Semimembranosus muscle heated unpacked in a water bath. Black line: sigmoid curve (Eq. (1)) fitting the experimental data. Letters indicate temperature effects on experimental data $(p<0.05)$.

the osmotic-like pressure in meat, the debinding of water from proteins and the migration of water in the product.

\subsection{Basic transport phenomena: effect of temperature, dimension and surrounding media}

Equilibrium states were determined every $5{ }^{\circ} \mathrm{C}$ from 50 to $90{ }^{\circ} \mathrm{C}$ in unsalted 5-mm semimembranosus discs heated unpacked in the water bath. $\mathrm{WL}_{\mathrm{eq}}, \mathrm{X}_{\mathrm{eq}}$ and $\mathrm{L}_{\mathrm{DMeq}}$ were significantly dependent on temperature $(\mathrm{p}=0.000)$. Fig. $2 \mathrm{~A}$ shows that the $\mathrm{X}_{\mathrm{eq}}$-curve on cubes was sigmoid, with a decrease of $\mathrm{X}_{\mathrm{eq}}$ between 60 and $80^{\circ} \mathrm{C} . \mathrm{WL}_{\mathrm{eq}}$ showed almost symmetrical evolution to $\mathrm{X}_{\mathrm{eq}}$ (Fig. $2 \mathrm{~B}$ ). The $\mathrm{X}_{\mathrm{eq}}$-curve was fitted with the sigmoid function used in the literature (Eq. (1)), with $\mathrm{a}_{0}=2.10 \mathrm{~g} / \mathrm{g} \mathrm{DM}$, $\mathrm{a}_{1}=0.94, \mathrm{a}_{2}=9.90, \mathrm{a}_{3}=-0.29$ and $\mathrm{T}_{\mathrm{r}}=58.9^{\circ} \mathrm{C}$. These parameters were specific of the studied muscle. Meat lost approximately $16 \%$ of DM when its final temperature was between 50 and $75^{\circ} \mathrm{C}$, the total loss of DM reached $21 \%$ when the final temperature was between 80 and $90{ }^{\circ} \mathrm{C}$ (for discs). Any direct comparison with $\mathrm{X}_{\mathrm{eq}}$ values from the literature always warrants caution as they are dependent on several parameters (studied in detail below), including surrounding fluid conditions, dimensions, $\mathrm{pH}$ in raw meat, etc., as well as on the DM basis used to express $\mathrm{X}_{\mathrm{eq}}$. However, the sigmoid shapes of the $\mathrm{X}_{\mathrm{eq}}{ }^{-}$and $\mathrm{WL}_{\mathrm{eq}}$-curves are similar to those found for beef (Davey \& Gilbert, 1974; Goni \& Salvadori, 2010) and rabbit (Combes, Lepetit, Darche, \& Lebas, 2004). Fig. 2A reports the equilibrium water content values found in the literature for beef (Goni \& Salvadori, 2010; van der Sman, 2007) and chicken filets (van der Sman, 2013). There are great difference between studies for $\mathrm{T} \leq 50{ }^{\circ} \mathrm{C}$ but closer values among different species for $\mathrm{T} \geq 60^{\circ} \mathrm{C}$, indicating that for increasing temperatures the 
overall mechanism should be the same whatever the species. However, even if the differences in $\mathrm{X}_{\mathrm{eq}}$ between studies first appear small in Fig. 2A, they can lead to great differences in the calculated WL. For example, after cooking at $80{ }^{\circ} \mathrm{C}, \mathrm{X}_{\mathrm{eq}}=1.0 \mathrm{~g} / \mathrm{g}$ DM for chicken fillets and $1.2 \mathrm{~g} / \mathrm{g}$ DM for beef meat, yet predicted weight loss was 50 and $45 \%$, respectively (with $\mathrm{X}_{0}=3.0 \mathrm{~g} / \mathrm{g} \mathrm{DM}$ ).

The DSC studies reported in the literature reveal that the first protein to denature when heated is myosin (peak transition at $54-58{ }^{\circ} \mathrm{C}$ ) (Tornberg, 2005). Hence at low temperatures (50 and $55^{\circ} \mathrm{C}$ ), the slight weight loss should essentially be due to myosin denaturation, resulting in water debinding. It is known in literature that during heating, myosin structure changed - myofibrillar and sarcoplasmic solubility decreased (Davey \& Gilbert, 1974) and protein hydrophobicity and aggregation increased (Promeyrat et al., 2013).

According to many authors, protein oxidation might play a major role in the decrease of water holding capacity of meat (Bertram et al., 2007; Huff-Lonergan \& Lonergan, 2005; Lund, Lametsch, Hviid, Jensen, \& Skibsted, 2007). For Bertram et al. (2007) and Lund et al. (2007), inter protein cross-links (disulfide or dityrosine cross-links), which lead to protein aggregation, may influence negatively the water holding capacity. Moreover, by generating cross-links, myosin oxidation strengthens the myofibrillar structure and increases shrinking of the overall muscle cell (Lund, Christensen, Fregil, Hviid, \& Skibsted, 2008). In addition to oxidation, the increase of protein surface hydrophobicity, observed when increasing temperature (Chelh, Gatellier, \& SantéLhoutellier, 2006), generates non-covalent protein aggregation and reduces water binding to protein. All these physico-chemical modifications of meat proteins should participate to juice loss.

Meat begins to contract strongly when its temperature reaches 55-60 ${ }^{\circ} \mathrm{C}$ (Bouhrara et al., 2012; Davey \& Gilbert, 1974), which coincides with the beginning of a sharp increase in the weight loss (Fig. 2). Meat contraction occurred in the same range of temperature as collagen denaturation. This comfort the mechanisms which proposed that collagen denaturation is a major factor in meat contraction (Miles, Avery, Rodin, \& Bailey, 2005; Tornberg, 2005). Within the same muscle, heated collagen follows different denaturation patterns according to its location in the different layers of connective tissue (epimysium, perimysium or endomysium) (Wu, Dutson, \& Smith, 1985). During cooking, in a first stage collagen fiber which is located around the myofiber is free to contract. After this first free-contraction stage the contraction of the collagen is limited by the resistance of the myofiber (forced contraction stage). It is assumed in literature that during this forced contraction stage, all other things being equal, the pressure developed by connective tissues is directly related to the stress exerted by collagen fibres (Lepetit, 2008). So, it is expected that the higher the amount of cross linked chains, the higher the thermal contraction of collagen fibres (Lepetit, 2008). The collagen network starts to contract when the temperature reaches $55-60^{\circ} \mathrm{C}$ but then this contraction continues over a broad temperature interval that can explain the observed increase in the meat weight loss. When the heating temperature is smaller than $50{ }^{\circ} \mathrm{C}$, it is the water located in the inter-fascicle spaces which is expelled out the sample. When the temperature increases, because of the pressure exerts on the myofibers by collagen water migrates from the intra-myofibril space to the inter-fascicle space (Realini et al., 2013). This migration is likely to bring denatured proteins out of the sample, which would explain the increase in the DM loss at higher temperatures. The partial destruction of cell membranes at high temperatures (Silva, Orcutt, Forrest, Bracker, \& Judge, 1993) could also promote DM loss in the cooking juice.

Unsalted SM with three sample dimensions - 40x5-mm discs, $30 \mathrm{x}$ 30 × 30-mm cubes and 50 × 50 × 50-mm cubes - was cooked unpacked at 50,70 and $90{ }^{\circ} \mathrm{C}$ until the equilibrium state was reached (i.e. for 60 , 120 and $240 \mathrm{~min}$, respectively). Dimension had a significant effect $(\mathrm{p}=0.000$ ) on equilibrium state (Fig. 3). Equilibrium water content was lower in discs than in cubes, meaning higher equilibrium weight loss. Differences in equilibrium water content in both sizes of cubes were only significant at $50{ }^{\circ} \mathrm{C}(\mathrm{P}<0.05)$. At higher temperature,

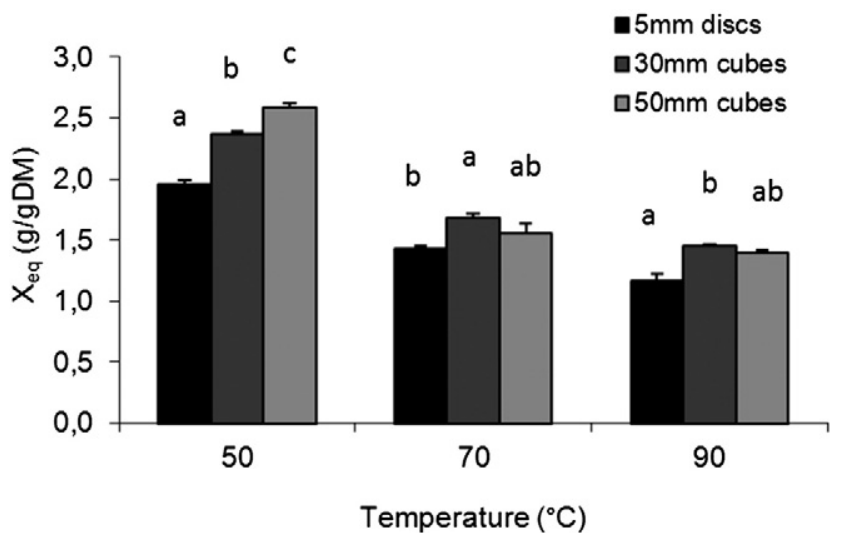

Fig. 3. Impact of sample dimensions on equilibrium water content $\left(\mathrm{X}_{\mathrm{eq}}\right)$ in pork Semimembranosus muscle samples cooked unpacked in a water bath. Letters indicate dimension effects $(\mathrm{p}<0.05)$ at constant heating temperature.

equilibrium water content was identical in all cubes whatever the sample dimensions (Fig. 3). Moreover, loss of DM in meat was systematically significantly higher in discs than in cubes $(P<0.05)$, while no difference was observed between cubes (not shown). Except at low temperature $\left(50{ }^{\circ} \mathrm{C}\right)$, dimension did not influence equilibrium state after heating the cubes, as shown elsewhere for beef meat (Bouton, Harris, \& Shorthose, 1976; Oillic et al., 2011).

Influence of the surrounding medium (water or juice) was studied on $40 \times 5-\mathrm{mm}$ discs and $30 \times 30 \times 30-\mathrm{mm}$ cubes heated unpacked or vacuum-packed in a water bath. The presence of the packaging introduced and additional resistance to the heat transfer and thus modifies the temperature kinetic in the product. However, this resistance did not affect the equilibrium temperature which was equal to the water bath temperature. This was checked during preliminary simulations based on measured heat transfer coefficient values. Since the results in Table 2 have been measured long after the meat temperature has reached the water bath temperature there were not affected by the difference in the heat transfer conditions due to the packaging. However, difference of mass transfer at equilibrium $\left(\mathrm{WL}_{\mathrm{eq}}, \mathrm{X}_{\mathrm{eq}}\right.$ and $\left.\mathrm{L}_{\mathrm{DMeq}}\right)$ between the packed and unpacked conditions were significant $(\mathrm{p}<0.05)$ for both the heated discs and cubes (Table 2$)$. Unpacked samples had significantly higher weight loss $(\mathrm{P}<0.05)$, lower water content and higher DM loss at equilibrium than packed samples. The influence of the surrounding fluid was higher at low temperature and on small samples (Table 2). The strong difference in weight loss observed between unpacked and packed samples at $50{ }^{\circ} \mathrm{C}$ occurred in the range of temperature of myosin denaturing which suggested a probable connection between the two phenomena. The difference in weight loss could be due to the difference in ion diffusion between the two treatment conditions. Meat heated in a sous vide bag is kept in contact with the cooking juice. Juice is coming from the water in the meat. This water phase contains ions which contribute to the osmotic pressure in the meat. There is no reason why these ions shall not flow out of the meat in the juice. Thus one can reasonably assume that there is almost the same ion concentration in the juice as in the meat piece, this would mean a close to zero ion diffusion. In the case of unpacked samples, ions are directly expelled into the water bath used as heating medium. This means an infinite dilution boundary condition for meatreleased ions and thus an acceleration of the ions diffusion out of the sample. These variations in the concentration of ions into the meat can have affected the protein denaturing. So, Hamm and Deatherage (1960) have demonstrated that divalent cations bound to muscle proteins can be released during heating like free ions and have also shown that some cations $\left(\mathrm{Mg}^{2+}\right.$ and $\mathrm{Mn}^{2+}$ ) have the ability to protect proteins from thermal denaturation.

At low heating temperature, the previously described ion diffusion process predominated, which would explain the higher differences in 
Table 2

Influence of boundary conditions on equilibrium weight loss $\left(\mathrm{WL}_{\mathrm{eq}}\right)$, equilibrium water content $\left(\mathrm{X}_{\mathrm{eq}}\right)$ and equilibrium dry matter loss $\left(\mathrm{L}_{\mathrm{DM}}\right.$ ).

\begin{tabular}{|c|c|c|c|c|c|}
\hline Dimension, $\mathrm{X}_{0}, \mathrm{pH}_{0}$ & Temperature $\left({ }^{\circ} \mathrm{C}\right)$ & Boundary conditions & $\mathrm{WL}_{\mathrm{eq}}(\%)$ & $\mathrm{X}_{\text {eq }}(\mathrm{g} / \mathrm{gDM})$ & $\mathrm{L}_{\text {DMeq }}(\%)$ \\
\hline Disc - 5 mm & 50 & Unpacked & $21.7 \pm 0.5 a$ & $1.99 \pm 0.02 \mathrm{a}$ & $15 \pm 3 a$ \\
\hline $\begin{array}{c}\mathrm{X}_{0}=2.8 \mathrm{~g} / \mathrm{gDM} \\
\mathrm{pH}_{0}=5.8\end{array}$ & & Vacuum-packed & $10.9 \pm 0.9 b$ & $2.41 \pm 0.03 b$ & $2 \pm 2 b$ \\
\hline Disc - $5 \mathrm{~mm}$ & 70 & Unpacked & $35.1 \pm 0.2 \mathrm{a}$ & $1.39 \pm 0.01 \mathrm{a}$ & $11 \pm 1 \mathrm{a}$ \\
\hline $\begin{array}{c}\mathrm{X}_{0}=2.7 \mathrm{~g} / \mathrm{gDM} \\
\mathrm{pH}_{0}=5.6\end{array}$ & & Vacuum-packed & $31.6 \pm 0.7 b$ & $1.52 \pm 0.02 b$ & $11 \pm 0 a$ \\
\hline Disc - $5 \mathrm{~mm}$ & 80 & Unpacked & $40.6 \pm 0.5 a$ & $1.38 \pm 0.02 \mathrm{a}$ & $18 \pm 0 a$ \\
\hline $\begin{array}{c}\mathrm{X}_{0}=3.0 \mathrm{~g} / \mathrm{gDM} \\
\mathrm{pH}_{0}=6.2\end{array}$ & & Vacuum-packed & $35.9 \pm 0.1 b$ & $1.56 \pm 0.01 b$ & $10 \pm 0 b$ \\
\hline Disc - $5 \mathrm{~mm}$ & 90 & Unpacked & $43.9 \pm 0.3 a$ & $1.24 \pm 0.01 a$ & $21 \pm 1 \mathrm{a}$ \\
\hline $\begin{array}{c}\mathrm{X}_{0}=3.0 \mathrm{~g} / \mathrm{gDM} \\
\mathrm{pH}_{0}=6.2\end{array}$ & & Vacuum-packed & $39.4 \pm 0.0 \mathrm{~b}$ & $1.42 \pm 0.00 \mathrm{~b}$ & $13 \pm 0 b$ \\
\hline Cube $-3 \mathrm{~cm}$ & 50 & Unpacked & $17.1 \pm 0.1 \mathrm{a}$ & $2.25 \pm 0.00 \mathrm{a}$ & $12 \pm 1 \mathrm{a}$ \\
\hline $\begin{array}{c}\mathrm{X}_{0}=2.9 \mathrm{~g} / \mathrm{gDM} \\
\mathrm{pH}_{0}=5.6\end{array}$ & & Vacuum-packed & $11.1 \pm 0.5 b$ & $2.48 \pm 0.02 b$ & $5 \pm 0 \mathrm{~b}$ \\
\hline Cube $-3 \mathrm{~cm}$ & 70 & Unpacked & $32.1 \pm 0.5 a$ & $1.76 \pm 0.02 \mathrm{a}$ & $8 \pm 2 a$ \\
\hline $\begin{array}{c}\mathrm{X}_{0}=3.1 \mathrm{~g} / \mathrm{gDM} \\
\mathrm{pH}_{0}=5.8\end{array}$ & & Vacuum-packed & $29.5 \pm 1.0 a$ & $1.87 \pm 0.04 a$ & $3 \pm 2 a$ \\
\hline
\end{tabular}

Packaging effect: letters indicate significant difference in a column for each temperature/'dimenion- $\mathrm{X}_{0}$ ' pair.

With $\mathrm{X}_{0}$ and $\mathrm{pH}_{0}$, the initial values of water content and $\mathrm{pH}$ of the samples.

weight loss observed at $50{ }^{\circ} \mathrm{C}$. Ion diffusivity in raw meat can reach 5.0 $10^{-10} \mathrm{~m}^{2} . \mathrm{s}^{-1}$ (Sharedeh, Favier, Auberger, Portanguen, \& Daudin, 2012), i.e. $1.8 \mathrm{~mm}^{2} \cdot \mathrm{h}^{-1}$. Therefore, in our range of experimental conditions. Thus, ions diffusion should only have affected a limited portion of the product. This can explain why greater differences in mass transfer were found between packed $v s$ unpacked discs rather than between packed $v s$ unpacked cubes. For instance, at $50{ }^{\circ} \mathrm{C}$, the difference in weight loss between the unpacked and packed samples was 1.8-fold higher for discs than for cubes ( $10.8 \%$ vs $6.0 \%$ respectively, Table 2 ).

When meat was heated above $70{ }^{\circ} \mathrm{C}$, weight losses increased strongly and were accompanied by a smaller difference in packed $v s$ unpacked loss. This suggested a change in the transport phenomena which evolved from diffusion to a contraction -driven mechanism; meat contraction having been observed on beef meat at this temperature (Bouhrara et al., 2012). Fig. 3 shows that there was also little difference in weight losses between discs and cubes heated directly in water at $70{ }^{\circ} \mathrm{C}$, where contraction is observed in literature.

Tests were performed to determine whether applying constraint forces to the meat surfaces has an effect on sample weight loss. When vacuum-packed cube samples were cooked with or without an additional $1 \mathrm{~kg}$ deadweight, $\mathrm{WL}_{\mathrm{eq}}$ and $\mathrm{X}_{\mathrm{eq}}$ were the same whatever the pressure applied.

\subsection{Impact of the properties of the raw unsalted sample}

$\mathrm{X}_{0}$ varied from 2.8 to $3.0 \mathrm{~g} / \mathrm{g}$ DM depending on location in the muscle. $\mathrm{X}_{0}$ and $\mathrm{pH}_{0}$ then measured on 104 different semimembranosus muscles varied from 2.5 to $3.3 \mathrm{~g} / \mathrm{g}$ DM and 5.5 to 6.1 respectively, with $50 \%$ of muscles having water content in the range 2.9-3.1 g/g DM and $\mathrm{pH}_{0}$ in the range 5.6-5.8. Thus, if the difference observed inside the sampled muscle is representative of what exists inside each of the muscles, the variability in $\mathrm{X}_{0}$ in the same muscle remained lower than the interanimal variability. Among raw SM muscles, $\mathrm{X}_{0}$ and $\mathrm{pH}_{0}$ were significantly $(p=0.000)$ and positively $(r=0.38)$ correlated. To identify whether this heterogeneity in $\mathrm{X}_{0}$ could influence equilibrium state in cooked meat, 40x5-mm discs cut in Semimembranosus of varying raw water content (from 2.5 to $3.0 \mathrm{~g} / \mathrm{g} \mathrm{DM}$ ) were cooked in a water bath at $65,75,80$ or $90{ }^{\circ} \mathrm{C}$. As water content in the raw meat was not controllable, it was impossible to achieve this manipulation in other conditions. The water content of $2.5 \mathrm{~g} / \mathrm{g}$ DM was highly unusual for pork Semimembranosus muscle. After being heated at 65 or $75^{\circ} \mathrm{C}$, the samples with the lowest $\mathrm{X}_{0}$ and $\mathrm{pH}_{0}$ had lower $\mathrm{X}_{\mathrm{eq}}$ and higher $\mathrm{WL}_{\mathrm{eq}}$ than the other samples (Table 3 ). At higher temperatures ( 80 and $90{ }^{\circ} \mathrm{C}$ ), differences in $\mathrm{WL}_{\mathrm{eq}}$ disappeared while differences in $\mathrm{X}_{\mathrm{eq}}$, although reduced, remained significant $(\mathrm{P}<0.05)$. Moreover, when meat was cooked above $75{ }^{\circ} \mathrm{C}$, the samples with the lowest $\mathrm{X}_{0}$ and $\mathrm{pH}_{0}$ lost more DM than the other samples (Table 3 ). When comparing $\mathrm{X}_{0}=$ 2.8 and $3.0 \mathrm{~g} / \mathrm{g} \mathrm{DM}$, the differences in $\mathrm{X}_{\mathrm{eq}}$ and $\mathrm{WL}_{\mathrm{eq}}$, although still persistent, were nevertheless weaker, in particular at high temperature (Table 3 ). When salting was performed by brine coating ( $\mathrm{pH}$ of the raw meat not controlled by immersion), the observed effect on $\mathrm{X}_{\mathrm{eq}}$ and $\mathrm{WL}_{\mathrm{eq}}$ could be mostly due to the variability of the $\mathrm{pH}$ in the raw meat: indeed it is known that weight loss decreases as meat $\mathrm{pH}$ moves away from the pI of meat protein (5.0) (Hamm \& Deatherage, 1960). During cooking, meat $\mathrm{pH}$ increased from 0.2 to 0.4 and this increase was dependent both on cooking temperature and, when meat was salted by brine coating, on the $\mathrm{pH}_{0}$ of the raw meat (Hamm \& Deatherage, 1960). Hence the reduced effect of $\mathrm{X}_{0}$ and $\mathrm{pH}_{0}$ on $\mathrm{WL}_{\mathrm{eq}}$ at high temperature $\left(80-90{ }^{\circ} \mathrm{C}\right)$ could be due to both the increased $\mathrm{pH}$ and the higher meat contraction.

Table 4 summarizes the raw meat characterization $\left(\mathrm{X}_{0}\right.$ and $\left.\mathrm{pH}_{0}\right)$ of the 5 studied muscles: RF, ST, SM, LT and BF. Raw-meat water content varied from 3.0 to $3.6 \mathrm{~g} / \mathrm{g}$ DM depending on muscle type. Through muscle type, $\mathrm{X}_{0}$ was significantly $(\mathrm{p}=0.002)$ correlated with $\mathrm{pH}_{0}$ $(r=0.65)$ : muscles with high water content tended to have higher $\mathrm{pH}_{0}$. The equilibrium state $\left(\mathrm{X}_{\mathrm{eq}}, \mathrm{WL}_{\mathrm{eq}}\right.$ and $\left.\mathrm{L}_{\mathrm{DMeq}}\right)$ was dependent on

Table 3

Influence of raw meat characterization (water content $\mathrm{X}_{0}$ and $\mathrm{pH}_{0}$ ) on equilibrium weight loss $\left(\mathrm{WL}_{\mathrm{eq}}\right)$, equilibrium water content $\left(\mathrm{X}_{\mathrm{eq}}\right)$ and equilibrium dry matter loss $\left(\mathrm{L}_{\mathrm{DMeq}}\right)$ in 5 -mm discs of pork Semimembranosus muscle cooked unpacked in a water bath at different temperatures.

\begin{tabular}{clccc}
\hline & $\begin{array}{l}\text { Heating } \\
\text { temperature } \\
\left({ }^{\circ} \mathrm{C}\right)\end{array}$ & Sample 1 & Sample 2 & Sample 3 \\
& & & & \\
\hline $\mathrm{X}_{0}(\mathrm{~g} / \mathrm{gDM})$ & & $\mathbf{2 . 4 7} \pm \mathbf{0 . 0 8 a}$ & $\mathbf{2 . 7 6} \pm \mathbf{0 . 0 3 b}$ & $\mathbf{3 . 0 2} \pm \mathbf{0 . 0 2 c}$ \\
$\mathrm{pH}_{0}$ & & $\mathbf{5 . 4 7} \pm \mathbf{0 . 0 2 a}$ & $\mathbf{5 . 7 5} \pm \mathbf{0 . 0 4 b}$ & $\mathbf{5 . 9 8} \pm \mathbf{0 . 0 4 c}$ \\
$\mathrm{X}_{\text {eq }}(\mathrm{g} / \mathrm{gDM})$ & 65 & $1.34 \pm 0.02 \mathrm{a}$ & $1.57 \pm 0.03 \mathrm{~b}$ & $1.98 \pm 0.02 \mathrm{c}$ \\
& 75 & $1.13 \pm 0.02 \mathrm{a}$ & $1.36 \pm 0.02 \mathrm{~b}$ & $1.63 \pm 0.03 \mathrm{c}$ \\
& 80 & $0.91 \pm 0.01 \mathrm{a}$ & $1.16 \pm 0.07 \mathrm{~b}$ & $1.24 \pm 0.01 \mathrm{~b}$ \\
& 90 & $32.6 \pm 0.6 \mathrm{a}$ & $30.6 \pm 0.9 \mathrm{a}$ & $26.1 \pm 0.6 \mathrm{~b}$ \\
$\mathrm{WL}_{\mathrm{eq}}(\%)$ & 65 & $38.8 \pm 0.5 \mathrm{a}$ & $36.7 \pm 0.6 \mathrm{ab}$ & $34.9 \pm 0.7 \mathrm{~b}$ \\
& 75 & $41.4 \pm 0.8 \mathrm{a}$ & $40.9 \pm 0.5 \mathrm{a}$ & $40.6 \pm 0.5 \mathrm{a}$ \\
& 80 & $16 \pm 3 \mathrm{a}$ & $18 \pm 1 \mathrm{a}$ & $16 \pm 1 \mathrm{a}$ \\
& 90 & $20 \pm 2 \mathrm{a}$ & $15 \pm 1 \mathrm{~b}$ & $15 \pm 1 \mathrm{~b}$ \\
$\mathrm{~L}_{\mathrm{DM} \text { Mq }}(\%)$ & 65 & $26 \pm 1 \mathrm{a}$ & $19 \pm 1 \mathrm{~b}$ & $18 \pm 0 \mathrm{~b}$ \\
& 75 & $28 \pm 1 \mathrm{a}$ & $17 \pm 4 \mathrm{~b}$ & $21 \pm 1 \mathrm{~b}$ \\
\hline & 80 & & $43.6 \pm 0.5 \mathrm{a}$ & $43.9 \pm 0.3 \mathrm{a}$ \\
& 90 & & &
\end{tabular}

Letters indicate significant differences $(\mathrm{p}<0.05)$ in a row. 
Table 4

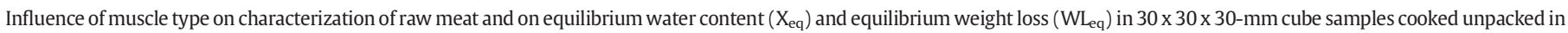
a water bath (120 min).

\begin{tabular}{|c|c|c|c|c|c|c|}
\hline \multirow[b]{3}{*}{ Muscle } & \multicolumn{2}{|l|}{ Raw meat } & \multicolumn{4}{|l|}{ Heated meat } \\
\hline & \multirow[b]{2}{*}{$\mathrm{pH}_{0}$} & \multirow[b]{2}{*}{$\mathrm{X}_{0}(\mathrm{~g} / \mathrm{gDM})$} & \multicolumn{2}{|l|}{$\mathrm{X}_{\mathrm{eq}}(\mathrm{g} / \mathrm{gDM})$} & \multicolumn{2}{|l|}{ WLeq (\%) } \\
\hline & & & $50{ }^{\circ} \mathrm{C}$ & $70^{\circ} \mathrm{C}$ & $50{ }^{\circ} \mathrm{C}$ & $70^{\circ} \mathrm{C}$ \\
\hline $\mathrm{RF}^{*}$ & $6.13 \pm 0.06 a$ & $3.55 \pm 0.04 \mathrm{a}$ & $3.24 \pm 0.18 \mathrm{a}$ & $1.74 \pm 0.06 a$ & $7.4 \pm 4.0 \mathrm{~b}$ & $39.7 \pm 0.5 a$ \\
\hline $\mathrm{ST}^{*}$ & $6.26 \pm 0.06 a$ & $3.24 \pm 0.08 b$ & $2.71 \pm 0.28 b$ & $1.70 \pm 0.05 a$ & $10.1 \pm 2.5 b$ & $38.2 \pm 1.1 \mathrm{ab}$ \\
\hline BF* & $5.76 \pm 0.04 b c$ & $3.05 \pm 0.03 b c$ & $2.21 \pm 0.01 b$ & $1.43 \pm 0.01 b$ & $21.1 \pm 0.3 a$ & $39.9 \pm 0.1 \mathrm{a}$ \\
\hline $\mathrm{LT}^{*}$ & $5.43 \pm 0.04 c$ & $3.02 \pm 0.04 b c$ & $2.32 \pm 0.01 b$ & $1.58 \pm 0.01 \mathrm{ab}$ & $18.8 \pm 0.3 a$ & $34.7 \pm 0.3 b c$ \\
\hline $\mathrm{SM}^{*}$ & $5.79 \pm 0.05 b$ & $3.03 \pm 0.04 c$ & $2.36 \pm 0.04 b$ & $1.69 \pm 0.03 a$ & $17.1 \pm 0.7 a$ & $32.8 \pm 0.9 c$ \\
\hline
\end{tabular}

Letters indicate significant differences $(\mathrm{p}<0.05)$ in a column.

With $\mathrm{X}_{0}$ and $\mathrm{pH}_{0}$, the initial values of water content and $\mathrm{pH}$ of the samples.

$* \mathrm{RF}=$ Rectus femoris, $\mathrm{ST}=$ Semitendinosus, $\mathrm{SM}=$ Semimembranosus, $\mathrm{LT}=$ Longissimus thoracis, $\mathrm{BF}=$ Biceps femoris.

muscle type $(\mathrm{p}=0.000)$. At $50{ }^{\circ} \mathrm{C}$, muscles with higher $\mathrm{pH}_{0}$ and $\mathrm{X}_{0}(\mathrm{RF}$ and ST) had lower $\mathrm{WL}_{\text {eq }}$ than the other muscles (Table 4 ), generalizing the impact of raw meat properties $\left(\mathrm{X}_{0}\right.$ and $\left.\mathrm{pH}_{0}\right)$ on the weight loss observed in the same muscle type (SM) at low temperature. At $70{ }^{\circ} \mathrm{C}, \mathrm{ST}$, RF and BF lost more juice than LT and SM (Table 4). BF and ST have higher collagen content than LT and SM (Wheeler, Shackelford, \& Koohmaraie, 2000), which should lead to greater meat contraction and thus more expulsed juice. This interpretation is in accordance with that of Brunton, Lyng, Zhang, and Jacquier (2006) who mentioned the previous works of Offer and Trinick (1983) and Bendall and Restall (1983).

\subsection{Impact of prior freezing}

Water content and $\mathrm{pH}$ in raw muscle was not pre-freezingdependent ( $p=0.292$ ), measuring $3.0 \pm 0.1 \mathrm{~g} / \mathrm{g}$ DM and $5.6 \pm 0.1$ regardless of whether the meat had been pre-frozen. The quantity of thawing juice was not measured here but has been estimated between 0.9 to $6.8 \%$ in the literature and is dependent on freezing and thawing rate (Yu et al., 2010), frozen temperature, and meat $\mathrm{pH}$ (Mortensen, Andersen, Engelsen, \& Bertram, 2006). Assuming the highest thawing loss (7\%), raw-meat water content would be $2.7 \mathrm{~g} / \mathrm{g}$ DM after thawing if thawing juice was pure water. However, as thawing juice is a mix of water and roughly 16\% DM (Thyholt \& Isaksson, 1997), raw-meat water content after thawing would be $2.9 \mathrm{~g} / \mathrm{g}$ DM - a value contained within the experimental variation of the water content in the raw meat (i.e. $\pm 0.1 \mathrm{~g} / \mathrm{g} \mathrm{DM}$ ). Thawing juice thus had a negligible impact on raw-meat water content due to DM loss in the thawing juice. According to literature, rapid freezing forms numerous small ice crystals while slow freezing forms bigger crystals which can alter the cell membrane, leading to higher juice loss (Hardman, 1989). In the present case, the freezing of the muscles was slow and the frozen muscles were stored for a short period (less than one month) before being cooked. Under these conditions pre-freezing did not influence water content in the cooked pork nor the weight losses (Fig. 1), as shown elsewhere for beef muscles (Oillic et al., 2011). The lack of effect of frozen storage could be linked to the fact that a short frozen storage (less than a month) did not influence myofibrillar protein denaturation (Paredi, Pagano, \& Crupkin, 2010; Xia, Kong, Liu, \& Liu, 2009). However, further research is needed to relate the structural change of meat and the protein denaturation to the weight losses of pre-frozen meat samples. For experimental convenience, the other experiments were performed on pre-frozen meat.

\subsection{Impact of salting}

Raw-meat water content can be enhanced by injection or by immersion in salted water. Two salting methods were used to salt discs: immersion and aspersion. Immersion led to a drastic increase ( $\mathrm{p}=$ 0.000 ) in water content from $2.99 \pm 0.04 \mathrm{~g} / \mathrm{g}$ DM in raw meat to $4.40 \pm 0.08 \mathrm{~g} / \mathrm{g} \mathrm{DM}$ in raw salted meat, i.e. an average weight gain of $35 \%$. This gain was concordant with the data of Wu et al. (2006) who observed a 25 to $45 \%$ weight gain during $48 \mathrm{~h}$ immersion in brine. When samples were salted by aspersion, water content was the same in unsalted and salted meat $(\mathrm{p}=0.932)$. Meat $\mathrm{pH}$ was between 5.6 and 5.7 and $\mathrm{X}_{\mathrm{eq}}$ differed strongly between immersed and non-immersed samples at $50{ }^{\circ} \mathrm{C},\left(\Delta \mathrm{X}_{\mathrm{eq}}=1.03 \mathrm{~g} / \mathrm{g} \mathrm{DM}\right)$ but was no longer significantly different at $70{ }^{\circ} \mathrm{C}\left(\Delta \mathrm{X}_{\mathrm{eq}}=0.10 \mathrm{~g} / \mathrm{g} \mathrm{DM}\right)$. At $70{ }^{\circ} \mathrm{C}$, the decrease of water content was faster for higher initial water content samples, rapidly ( $5 \mathrm{~min}$ ) reaching the same water content as "non-enhanced samples". A drastic increase of initial water content had an effect on water content in cooked meat, but only when temperature was lower than the temperature at which meat started to contract (i.e. $55-60{ }^{\circ} \mathrm{C}$ ): the same quantity of water gained was lost as soon as the meat contracted. In industrial meat processing, brine injection is often used to salt products, which increases in raw-meat water content. Then muscles are tumbled.

Salt content significantly influenced $\mathrm{WL}_{\mathrm{eq}}$ and $\mathrm{X}_{\mathrm{eq}}$ but not $\mathrm{L}_{\mathrm{DM} \text { eq. }}$. Results for cubes were similar for $40 \times 5-\mathrm{mm}$ discs and are presented in Fig. 4. Equilibrium weight losses were higher for unsalted than salted samples, but without significant difference in equilibrium weight loss between sample salting conditions. In the literature, any reported differences in weight loss due to $0.5 \%$ differences in salt content remain small. To be quantified, they would require repeating the experiments with the same muscle type, having the same $\mathrm{pH}$ and the same $\mathrm{X}_{0}$, and using a wide range of temperature conditions, and the analyst would also have make doubly sure that the sample is uniformly salted. However, these conditions are not always verified in literature reports. Here, the experiments were heavily repeated between 50 and $90{ }^{\circ} \mathrm{C}$ using the same muscle type, controlling $\mathrm{pH}$, and measuring the $\mathrm{X}_{0}$ value of each sample. We did not observe any statistical effect of salt content as soon as the sample was salted. This was true whatever the temperature, even if trends started to emerge at $70{ }^{\circ} \mathrm{C}$. In presence of salt $(0.8$ $2 \%$ ), the increase of salt content led to an increase in osmotic-like pressure in the meat (Offer \& Knight, 1988) and an increase in protein denaturation (Villamonte et al., 2013). These two phenomena had contradictory effects - increasing water retention and increasing water debinding - that could have cancelled each other out, which would explain the absence of differences in weight loss in our experiments.

\subsection{Effect of previous results on the prediction of the weight loss}

The results showed that the primary factor influencing weight loss was cooking temperature. At temperatures below the $55-60{ }^{\circ} \mathrm{C}$ range weight loss is small while it increases greatly above this threshold. This can be connected to what is known in literature on the denaturation and contraction of the major proteins which constitute the muscle. Below the previous temperature threshold myosin denatures, while above this threshold collagen contracts. According to Hardman (1989), the denaturation of myosin starts about $40{ }^{\circ} \mathrm{C}$ ending at about $60{ }^{\circ} \mathrm{C}$, followed by sarcoplasmic proteins and collagen denaturation. Finally, the myofibrillar protein actin or actomyosin denatures between 


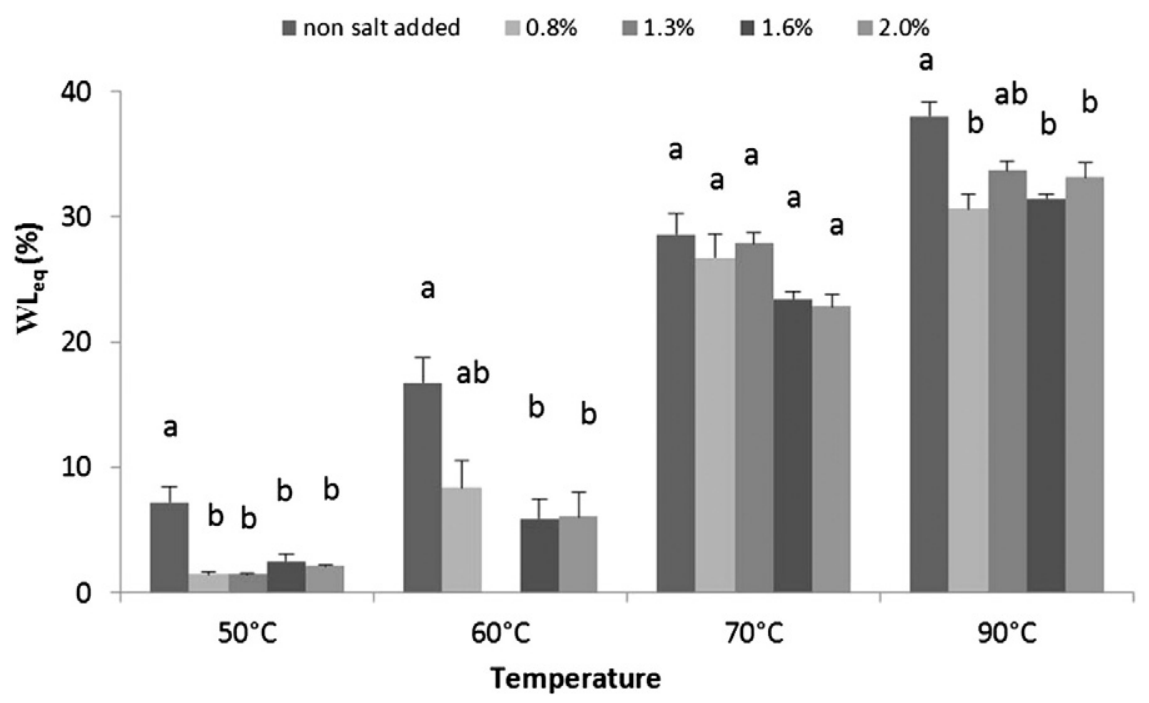

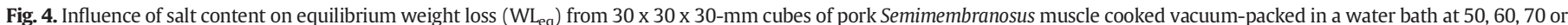
$90{ }^{\circ} \mathrm{C}$. Lowercase letters indicate salt content effects $(\mathrm{p}<0.05)$ at constant heating temperature.

$75-80{ }^{\circ} \mathrm{C}$. A handful of factors tested had no significant influence on weight loss: pre-freezing the meat, mold pressure during cooking, and varying salt content from $0.8 \%$ to $2.0 \%$. The other factors tested $\left(\mathrm{pH}_{0}\right.$ and $\mathrm{X}_{0}$, boundary conditions, size, water enhancement) had a strong impact at $50{ }^{\circ} \mathrm{C}$ but less if any effect above the temperature triggering collagen contraction. Testing the boundary conditions revealed a strong impact of ion diffusion on water debinding in the thin-sliced meat samples. Raw material variability had effects on subsequent weight losses: low $\mathrm{pH}_{0}$ (close to 5.5), which was correlated with low initial water content $\mathrm{X}_{0}$, led to higher weight losses than the meat with the higher $\mathrm{pH}_{0}$ (6.0). This was probably due to the fact that the proteins move closer to their pI which has been found to be close to 5.0 on unsalted minced pork meat (Offer \& Knight, 1988). French industry practice selects meat based on $\mathrm{pH}$ : the average $\mathrm{pH}$ accepted for the ham industry is 5.6-5.9, and ham is usually cooked at a temperature of $70{ }^{\circ} \mathrm{C}$. Our results showed that an increase of $\mathrm{pH}$ from 5.8 to 6.0 in raw meat could lead to a decrease of between $1.8 \%$ and $4.5 \%$ in weight loss at a temperature of $70{ }^{\circ} \mathrm{C}$. The muscle-type effect was explained by an effect of $\mathrm{pH}_{0}$ and $\mathrm{X}_{0}$ coupled with an effect of different composition at $50{ }^{\circ} \mathrm{C}$ and by different meat contraction dynamics at $70{ }^{\circ} \mathrm{C}$.

\section{Conclusion}

This study, working under fully controlled experimental conditions, highlighted the key influential factors of the weight losses and water content in water bath heated meat. The effects of these different factors have been interpreted using the knowledge of literature on the denaturation and contraction of proteins, or on water migration but without measuring these phenomena.

Weight loss can be actually predicted from mass transfer models based on the water content components by taking certain precautions. The water content in meat can be determined from the difference between water content at a given time and equilibrium water content $\left(X-X_{e q}\right)$ (Kondjoyan et al., 2013a). However, the water content calculation needs to integrate dry matter loss, Eq. (4) clearly shows that predicted weight loss was highly sensitive to $\mathrm{X}_{0}$ which was $\mathrm{pH}_{0}$-dependent and had an impact on $\mathrm{X}_{\mathrm{eq}}$. The analysis of raw meat shows that the $\mathrm{X}_{\mathrm{eq}}$ determined in order to predict weight loss has to be measured on samples with $\mathrm{pH}_{0}$ and $\mathrm{X}_{0}$ values not too far from the average (e.g. for pork SM: $\mathrm{X}_{0} \sim 3.0 \mathrm{~g} / \mathrm{g} \mathrm{DM}$ and $\left.\mathrm{pH}_{0} \sim 5.7\right)$. The prediction will then be accurate however for a limited range of $\mathrm{X}_{0}$ and $\mathrm{pH}_{0}$. This is coherent with the simulation of a real production of cooked hams since industry selects raw meat based on $\mathrm{pH}_{0}$ (at 5.6-5.9). For "unusual" $\mathrm{pH}_{0}$ and $\mathrm{X}_{0}$, prediction will nevertheless be able to highlight the relative influence of processes on weight loss. $\mathrm{X}_{0}$ and $\mathrm{X}_{\mathrm{eq}}$ can also be measured for the new range of $\mathrm{pH}$ or for the new composition of the product. $\mathrm{X}_{\mathrm{eq}}$ has however to be determined on several temperatures, and a smoothing function (Eq. (1)) makes it possible to assess $X_{\text {eq }}$ at each temperature. We investigated the influence of dimension-related variation of $\mathrm{X}_{\mathrm{eq}}$ in the prediction of $\mathrm{WL}_{\mathrm{eq}}$ (Table 5). Predicted $\mathrm{WL}_{\mathrm{eq}}$ from the mean $\mathrm{X}_{\mathrm{eq}}$ found on cubes ( $30 \times 30 \times 30 \mathrm{~mm}$ cubes plus $50 \times 50 \times 50 \mathrm{~cm}$ cubes) led to a maximal absolute difference of $2.7 \%$ compared to the $\mathrm{WL}_{\mathrm{eq}}$ predicted from the measured $\mathrm{X}_{\mathrm{eq}}$. The maximal difference was reached at $50{ }^{\circ} \mathrm{C}$ and was lower at higher temperature. $\mathrm{X}_{\mathrm{eq}}$ has to be determined on cubes to be able to predict weight loss whatever the meat dimension. Determining $\mathrm{X}_{\mathrm{eq}}$ on small samples, as Goni and Salvadori (2010) did, could introduce a bias in the predicted weight loss that may reach $15 \%$ at low temperature (Table 5). Because $\mathrm{X}_{\text {eq }}$ was dependent on muscle type, on cooking process and on presence of salt, predictions have to factor in conditions such as cooking in-bag or directly in water ("courtbouillon"), and presence or absence of salt.

On the contrary, weight loss is unaffected by constraints applied at the meat sample surface or whether or not the sample is pre-frozen, and is also probably unaffected by the shape (disc or cube) or size of this sample. Unsalted and $0.8 \%$ salt content samples showed differences in water content and weight loss under our experimental conditions. However, samples with salt contents varying from 0.8 to $2 \%$ showed no quantifiable differences. If this finding is confirmed for

\section{Table 5}

Influence of the determination of $\mathrm{X}_{\mathrm{eq}}$ on the prediction of the weight loss from Eq. (4) with $\mathrm{X}_{0}=3.0 \mathrm{~g} / \mathrm{gDM}$.

\begin{tabular}{rllllllr}
\hline & $\mathrm{T}\left({ }^{\circ} \mathrm{C}\right)$ & $\begin{array}{l}\text { Experimental } \\
\mathrm{X}_{\mathrm{eq}}\left(\mathrm{g} / \mathrm{gMS}_{0}\right)\end{array}$ & $\begin{array}{l}\mathrm{WL}_{\mathrm{eq1} 1} * \\
(\%)\end{array}$ & $\begin{array}{l}\mathrm{WL}_{\mathrm{eq} 2} * * \\
(\%)\end{array}$ & $\begin{array}{l}\mathrm{WL}_{\mathrm{eq} 1}- \\
\mathrm{WL}_{\mathrm{eq} 2} \\
(\%)\end{array}$ & $\begin{array}{l}\mathrm{WL}_{\mathrm{eq} 3} * * * \\
(\%)\end{array}$ & $\begin{array}{l}\mathrm{WL}_{\mathrm{eq} 1}- \\
\mathrm{WL}_{\mathrm{eq} 3} \\
(\%)\end{array}$ \\
\hline $30 \mathrm{~mm}$ & 50 & 2.36 & 15.9 & 13.2 & -2.7 & 26.0 & 10.1 \\
cubes & 70 & 1.69 & 32.9 & 34.5 & 1.6 & 39.4 & 6.5 \\
& 90 & 1.45 & 38.8 & 39.5 & 0.7 & 45.9 & 7.0 \\
$50 \mathrm{~mm}$ & 50 & 2.58 & 10.4 & 13.2 & 2.7 & 26.0 & 15.6 \\
cubes & 70 & 1.56 & 36.0 & 34.5 & -1.6 & 39.4 & 3.3 \\
& 90 & 1.39 & 40.2 & 39.5 & -0.7 & 45.9 & 5.7 \\
\hline
\end{tabular}

Eq. (4) used for calculations: $W L=\frac{X_{0}-X}{1+X_{0}} \times 100$

$* \mathrm{WL}_{\mathrm{eq} 1}$ predicted from experimental $\mathrm{X}_{\mathrm{eq}}$.

$* * \mathrm{WL}_{\mathrm{eq} 2}$ predicted from the mean of $\mathrm{X}_{\mathrm{eq}}$ for cubes.

*** $\mathrm{WL}_{\mathrm{eq}}$ predicted from the $\mathrm{X}_{\mathrm{eq}}$ for discs. 
injected and tumbled meat muscle, it would enable industry processors to reduce product salt content without having to use additives like polyphosphates.

$\begin{array}{ll}\text { Nomenclature } \\ \text { DM } & \text { dry matter } \\ \text { X } & \text { water content } \\ \text { WL } & \text { weight loss } \\ \text { LDM }_{\mathrm{DM}} & \text { loss of dry matter } \\ \text { SEM } & \text { standard error of the mean } \\ \text { WL } & \text { weight loss }\end{array}$

\section{Muscle type}

SM Semimembranosus

BF Biceps femoris

$\mathrm{RF} \quad$ Rectus femoris

ST Semitendinosus

LT Longissimus thoracis

\author{
Subscripts \\ $0 \quad$ value for the raw sample \\ eq value at the equilibrium state
}

\section{Acknowledgements}

This work was funded by the Na- integrated program (ANR-09ALIA-013-01) financed by the French National Research Agency. The authors thank Jeanne Danon and Aurélien Latour for their involvement in the experimental work, and the ADIV for letting us use their tumbler.

\section{Conflict of interest}

There is no conflict of interest.

\section{References}

Aaslyng, M. D., Bejerholm, C., Ertbjerg, P., Bertram, H. C., \& Andersen, H. J. (2003). Cooking loss and juiciness of pork in relation to raw meat quality and cooking procedure. Food Quality and Preference, 14(4), 277-288.

Baublits, R. T., Pohlman, F. W., Brown, A. H., Yancey, E. J., \& Johnson, Z. B. (2006). Impact of muscle type and sodium chloride concentration on the quality, sensory, and instrumental color characteristics of solution enhanced whole-muscle beef. Meat Science, 72(4), 704-712.

Bendall, J. R., \& Restall, D. J. (1983). The cooking of single myofibres, small myofibre bundles and muscle strips from beef M. psoas and M. sternomandibularis muscles at varying heating rates and temperatures. Meat Science, 8(2), 93-117.

Bertram, H. C., Kristensen, M., Ostdal, H., Baron, C. P., Young, J. F., \& Andersen, H. J. (2007), Does oxidation affect the water functionality of myofibrillar proteins. Journal of Agricultural and Food Chemistry, 55, 2342-2348.

Boles, J. A., \& Shand, P. J. (2001). Meat cut and injection level affects the tenderness and cook yield of processed roast beef. Meat Science, 59(3), 259-265.

Bouhrara, M., Clerjon, S., Damez, J. L., Kondjoyan, A., \& Bonny, J. M. (2012). In situ imaging highlights local structural changes during heating: the case of meat. Journal of Agricultural and Food Chemistry, 60(18), 4678-4687.

Bouton, P. E., Harris, P. V., \& Shorthose, W. R. (1976). Factors influencing cooking losses from meat. Journal of Food Science, 41(5), 1092-1095.

Brunton, N. P., Lyng, J. G., Zhang, L., \& Jacquier, J. C. (2006). The use of dielectric properties and other physical analyses for assessing protein denaturation in beef Biceps femoris muscle during cooking from 5 to $85^{\circ} \mathrm{C}$. Meat Science, $72(2), 236-244$.

Chelh, I., Gatellier, P., \& Santé-Lhoutellier, V. (2006). Technical note: A simplified procedure for myofibril hydrophobicity determination. Meat Science, 74, 681-684.

Cheng, Q. F., \& Sun, D. W. (2007). Effect of cooking bag and netting packaging on the quality of pork ham during water cooking. Meat Science, 75(2), 243-247.

Cheng, Q., Sun, D. W., \& Scannell, A. (2005). Feasibility of water cooking for pork ham processing as compared with traditional dry and wet air cooking methods. Journal of Food Engineering, 67(4), 427-433.

Combes, S., Lepetit, J., Darche, B., \& Lebas, F. (2004). Effect of cooking temperature and cooking time on Warner-Bratzler tenderness measurement and collagen content in rabbit meat. Meat Science, 66(1), 91-96.
Davey, C. L., \& Gilbert, K. V. (1974). Temperature-dependent cooking toughness in beef. Journal of Science of Food and Agriculture, 25, 931-938.

Desmond, E. M., Kenny, T. A., \& Ward, P. (2002). The effect of injection level and cooling method on the quality of cooked ham joints. Meat Science, 60(3), 271-277.

Desmond, E. (2006). Reducing salt: A challenge for the meat industry. Meat Science, 74(1), 188-196.

Detienne, N. A., \& Wicker, L. (1999). Sodium chloride and tripolyphosphate effects on physical and quality characteristics of injected pork loins. Journal of Food Science, 64(6), 1042-1047.

Feyissa, A. H., Gernaey, K. V., \& Adler-Nissen, J. (2013). 3D modelling of coupled mass and heat transfer of a convection-oven roasting process. Meat Science, 93(4), 810-820.

Goni, S. M., \& Salvadori, V. O. (2010). Prediction of cooking times and weight losses during meat roasting. Journal of Food Engineering, 100(1), 1-11.

Hamm, R. (1972). Kolloidchemie des Fleisches. Berlin and Hamburg: Paul Parey.

Hamm, R., \& Deatherage, F. E. (1960). Changes in hybridation, solubility and charges of muscle proteins during heating of meat. Journal of Food Science, 25, 587-610.

Hardman, T. M. (1989). Water and food quality. (1 ed.). London: Elsevier Applied Science.

Hsu, S. Y., \& Yu, S. H. (1999). Effects of phosphate, water, fat and salt on qualities of lowfat emulsified meatball. Journal of Food Engineering, 39(2), 123-130.

Huff-Lonergan, E., \& Lonergan, S. M. (2005). Mechanisms of water-holding capacity of meat: The role of postmortem biochemical and structural changes. Meat Science, 71, 194-204.

Jeong, J. Y., Lee, E. S., Choi, J. H., Lee, J. Y., Kim, J. M., Min, S. G., Chae, Y. C., \& Min, C. J. (2007). Variability in temperature distribution and cooking properties of ground pork patties containing different fat level and with/without salt cooked by microwave energy. Meat Science, 75(3), 415-422.

Jeremiah, L. E., Dugan, M. E. R., Aalhus, J. L., \& Gibson, L. L. (2003). Assessment of the chemical and cooking properties of the major beef muscles and muscle groups. Meat Science, 65, 985-992.

Kondjoyan, A., Kohler, A., Realini, C. E., Portanguen, S., Kowalski, R., Clerjon, S., Gatellier, P., Chevolleau, S., Bonny, J. -M., \& Debrauwer, L. (2014). Towards models for the prediction of beef meat quality during cooking. Meat Science, 97(3), 323-331.

Kondjoyan, A., Oillic, S., Portanguen, S., \& Gros, J. -B. (2013a). Combined heat transfer and kinetic models to predict cooking loss during heat treatment of beef meat. Meat Science, 95(2), 336-344.

Lee, K. C., \& Chin, K. B. (2011). Evaluation of various salt levels and different dairy proteins in combination with microbial transglutaminase on the quality characteristics of restructured pork ham. International Journal of Food Science E Technology, 46(7), $1522-1528$.

Lepetit, J. (2008). Collagen contribution to meat toughness: Theoretical aspects. Meat Science, 80(4), 960-967.

Lund, M. N., Christensen, M., Fregil, L., Hviid, M. S., \& Skibsted, L. H. (2008). Effect of highoxygen atmosphere packaging in mechanical properties of single muscle fibres from bovine and porcine Longissimus dorsi. European Food Research and Technology, 227, 1323-1328.

Lund, M. N., Lametsch, R., Hviid, M. S., Jensen, O. N., \& Skibsted, L. H. (2007). High-oxygen atmosphere influences protein oxidation and tenderness of porcine Longissimus dorsi during chill storage. Meat Science, 77, 295-303.

Miles, C. A., Avery, N. C., Rodin, V. V., \& Bailey, A. J. (2005). The increase in denaturation temperature following cross-linking of collagen is caused by dehydration of the fibres. Journal of Molecular Biology, 346(2), 551-556.

Mortensen, M., Andersen, H. J., Engelsen, S. B., \& Bertram, H. C. (2006). Effect of freezing temperature, thawing and cooking rate on water distribution in two pork qualities. Meat Science, 72(1), 34-42.

Offer, G., \& Knight, P. (1988). The structural basis of water-holding in meat. In R. Lawrie (Ed.), Developments in Meat Science, 4. (pp. 63-243). London: Elsevier Applied Science (Chapter 3-4).

Offer, G., \& Trinick, J. (1983). On the mechanism of water holding in meat: The swelling and shrinking of myofibrils. Meat Science, 8(4), 245-281.

Oillic, S., Lemoine, E., Gros, J. B., \& Kondjoyan, A. (2011). Kinetic analysis of cooking losses from beef and other animal muscles heated in a water bath - Effect of sample dimensions and prior freezing and ageing. Meat Science, 88(3), 338-346.

Paredi, M., Pagano, M. \& Crupkin, M. (2010). Biochemical and physicochemical properties of actomyosin and myofibrils from frozen stored flounder (Paralichthys patagonicus) fillets. Journal of Food Biochemistry, 34(5), 983-997.

Promeyrat, A., Daudin, J. D., \& Gatellier, P. (2013). Kinetics of protein physicochemical changes induced by heating in meat using mimetic models: (1) Relative effects of heat and oxidants. Food Chemistry, 138(1), 581-589.

Puolanne, E., \& Halonen, M. (2010). Theoretical aspects of water-holding in meat. Meat Science, 86(1), 151-165.

Puolanne, E., Ruusunen, M. H., \& Vainionpaa, J. I. (2001). Combined effects of $\mathrm{NaCl}$ and raw meat $\mathrm{pH}$ on water-holding in cooked sausage with and without added phosphate. Meat Science, 58(1), 1-7.

Realini, C. E., Venien, A., Gou, P., Gatellier, P., Perez-Juan, M., Danon, J., \& Astruc, T. (2013). Characterization of Longissimus thoracis, Semitendinosus and Masseter muscles and relationships with technological quality in pigs. 1. Microscopic analysis of muscles. Meat Science, 94(3), 408-416.

Rhee, M. S., Wheeler, T. L., Shackelford, S. D., \& Koohmaraie, M. (2004). Variation in palatability and biochemical traits within and among eleven beef muscles. Journal of Animal Science, 82(2), 534-550.

Sharedeh, D., Favier, R., Auberger, J. M., Portanguen, S., \& Daudin, J. D. (2012). A laboratory tumbler simulator- Salt penetration improvement due to meat mechanical treatment. 58th International Congress of Meat Science and Technology (ICoMST). August 12-17, Montreal, Canada. 
Sikes, A. L., Tobin, A. B., \& Tume, R. K. (2009). Use of high pressure to reduce cook loss and improve texture of low-salt beef sausage batters. Innovative Food Science E' Emerging Technologies, 10(4), 405-412.

Silva, T. J. P., Orcutt, M. W., Forrest, J. C., Bracker, C. E., \& Judge, M. D. (1993). Effect of heating rate on shortening, ultrastructure, and fracture behavior of prerigor beef muscle. Meat Science, 33(1), 1-24.

Thyholt, K., \& Isaksson, T. (1997). Differentiation of frozen and unfrozen beef using near-infrared spectroscopy. Journal of the Science of Food and Agriculture, 73(4), 525-532.

Tornberg, E. (2005). Effects of heat on meat proteins - Implications on structure and quality of meat products. Meat Science, 70(3), 493-508.

Utrera, M., Armenteros, M., Ventanas, S., Solano, F., \& Estevez, M. (2012). Pre-freezing raw hams affects quality traits in cooked hams: Potential influence of protein oxidation. Meat Science, 92(4), 596-603.

van der Sman, R. G. M. (2007). Moisture transport during cooking of meat: An analysis based on Flory-Rehner theory. Meat Science, 76(4), 730-738.

van der Sman, R. G. M. (2013). Modeling cooking of chicken meat in industrial tunnel ovens with the Flory-Rehner theory. Meat Science, 95(4), 940-957.

Vaudagna, S. R., Pazos, A. A., Guidi, S. M., Sanchez, G., Carp, D. J., \& Gonzalez, C. B. (2008) Effect of salt addition on sous vide cooked whole beef muscles from Argentina. Meat Science, 79(3), 470-482.
Villamonte, G., Simonin, H., Duranton, F., Cheret, R., \& de Lamballerie, M. (2013). Functionality of pork meat proteins: Impact of sodium chloride and phosphates under high-pressure processing. Innovative Food Science \& Emerging Technologies, 18, 15-23.

Wheeler, T. L., Shackelford, S. D., \& Koohmaraie, M. (2000). Variation in proteolysis, sarcomere length, collagen content, and tenderness among major pork muscles. Journal of Animal Science, 78(4), 958-965.

Wu, Z., Bertram, H. C., Kohler, A., Bocker, U., Ofstad, R., \& Andersen, H. J. (2006). Influence of aging and salting on protein secondary structures and water distribution in uncooked and cooked pork. A combined FT-IR microspectroscopy and H-1 NMR relaxometry study. Journal of Agricultural and Food Chemistry, 54(22) 8589-8597.

Wu, F. Y., Dutson, T. R., \& Smith, S. B. (1985). A scanning electron microscopy study of heatinduced alterations in bovine connective tissue. Journal of Food Science, 50(4), 1041-1044.

Xia, X., Kong, B., Liu, Q., \& Liu, J. (2009). Physicochemical change and protein oxidation in porcine Longissimus dorsi as influenced by different freeze-thaw cycles. Meat Science 83(2), 239-245.

Yu, X. L., Li, X. B., Zhao, L., Xu, X. L., Ma, H. J., Zhou, G. H., \& Boles, J. A. (2010). Effects of different freezing rates and thawing rates on the manufacturing properties and structure of pork. Journal of Muscle Foods, 21(2), 177-196. 